\title{
Mandatory Advisory Counsel for Pro Se Defendants: Maintaining Fairness in the Criminal Trial
}

In People v. Joseph, ${ }^{1}$ the California Supreme Court strengthened a defendant's sixth amendment right to conduct her own criminal defense. The court based its ruling on a strict reading of the United States Supreme Court's holding in Faretta v. California, ${ }^{2}$, which placed the right to a pro se defense on an independent constitutional foundation. As a result, Cahfornia law provides that a defendant who waives the right to an attorney effectively waives all the traditional protections such representation may provide.

However, the California Supreme Court's strict reading of Faretta inadequately addresses the fundamental collision between an individual defendant's riglit to autonomy and society's interest in safeguarding the fairness of the trial system. The emphasis of sixth amendment jurisprudence on the right to a fair trial makes it critical that the court adopt procedures designed to minimize the potentially destructive effects-both for the individual defendant and the judicial system as a whole-of a defendant's waiver of counsel. This Comment proposes that the California Supreme Court mandate the appointment of a form of standby advisory counsel in all pro se criminal defense cases. Part I examines the Joseph case, the most recent expression of Cahfornia law on self-representation, and the roots of the pro se right as expressed in Faretta. Part II considers the fairness requirements of the sixth amendment and the dual interest in individual and societal justice that the sixth amendment has been interpreted to serve. Part II suggests that the same concerns which mandate the appoimtment of counsel for indigents compel the courts to safeguard the interests of the pro se defendant. Part III offers a specific proposal for mandatory standby advisory counsel and analyzes some of the practical questions that standby counsel raises.

1. 34 Cal. 3d 936, 671 P.2d 843, 196 Cal. Rptr. 339 (1983).

2. 422 U.S. 806 (1975). 


\section{I \\ PEople V. Joseph and California LaW on Self- REPRESENTATION}

\section{A. The Joseph Decision}

Mariney Joseph was accused of a murder committed during a robbery and faced a possible death sentence. ${ }^{3}$ Five months before his trial began, Joseph and his attorney appeared for a pretrial conference during which the attorney requested to be excused from the case because of differences with his chent. Joseph moved to represent hilnself. ${ }^{4}$ The judge relieved the attorney, but refused to allow Joseph to represent himself. Pointing to the severity of the potential sanction in a capital case $^{5}$ the judge explained, "[Y]ou are not able to represent yourself effectively because of the nature of the charge . . ." The trial court then appoimted other counsel. ${ }^{7}$ Joseph was subsequently convicted and sentenced to death. ${ }^{8}$

On direct appeal, the California Supreme Court overturned Joseph's conviction solely because of the trial court's refusal to permit him to represent himself. ${ }^{9}$ The court based its ruling on the United States Supreme Court's holding in Faretta v. California that a defendant has an independent constitutional right to proceed without counsel when he has knowingly and intelligently elected to do so. ${ }^{10}$ The Joseph court held that if a defendant knowingly and intelligently chooses to proceed without representation, the trial court must permit a pro se defense. The trial court inay not inquire into the wisdom of that choice; ${ }^{11}$ the request must be granted as long as it is timely. ${ }^{12}$ In effect, the mentally competent defendant's ability to knowingly and voluntarily waive the assistance of counsel is relevant, while his capacity to conduct an adequate defense is not. ${ }^{13}$

The court further held that Joseph's repeated acknowledgment of both the seriousness of the charge against him and the possibility that he miglit face a death penalty sufficed to bind the trial court to honor

3. People v. Joseph, 34 Cal. 3d 936, 939, 671 P.2d 843, 844, 196 Cal. Rptr. 339, 340 (1983).

4. Id. at $939-40,671$ P.2d at 845,196 Cal. Rptr. at 341.

5. Id. at 942,671 P.2d at 846,196 Cal. Rptr. at 342.

6. Id.

7. Id. at 943,671 P.2d at 846,196 Cal. Rptr. at 342 .

8. Id. at 939,671 P.2d at 844,196 Cal. Rptr. at 340.

9. Id. at 939,671 P.2d at $844-45,196$ Cal. Rptr. at $340-41$.

10. 422 U.S. $806,807,819-21$ (1975).

11. $34 \mathrm{Cal} .3 \mathrm{~d}$ at 943,671 P.2d at $846-47,196 \mathrm{Cal}$. Rptr. at $342-43$ (citing Ferrel v. Superior Court, 20 Cal. 3d 888, 891, 576 P.2d 93, 95, 144 Cal. Rptr. 610, 612 (1978)).

12. Id. at 944,671 P.2d at 847,196 Cal. Rptr. at 343.

13. Id. at 943,671 P.2d at 847,196 Cal. Rptr. at 343. 
his request. ${ }^{14}$ The nature of the charge and the potential severity of the punishment were irrelevant to the assessment of Joseph's capacity to defend himself. ${ }^{15}$ Rather, it was enough that Joseph was "literate, competent, and understanding" 16 and that he was "voluntarily exercising his informed free will."17

Noting that the motivation for the Faretta rule was respect for the accused's autonoiny and freedoin of choice to conduct his own defense, ${ }^{18}$ the court held that when a timely request involving a knowing and intelligent waiver is denied, only a per se rule of reversal is appropriate. Such an automatic rule ensures that "the accused's freedoin of choice will be scrupulously honored out of 'respect for the individual which is the lifeblood of the law." "19 Any attempt to apply a harmless error test would erode the pro se right itself. ${ }^{20}$ This approach is in accord with unost federal and lower California court decisions. ${ }^{21}$

In a concurring opinion, Justice Mosk suggested that the right in Faretta "is not as absolute as the inajority opinion implies. Under some circumstances there inay be a linitation on the right of self representation, particularly im a capital case." $22 \mathrm{He}$ noted that the court has refused to permit a capital defendant to plead guilty over the objection of his attorney ${ }^{23}$ and that "the state has an interest in the proceedings that cannot be extinguished." 24 The defendant "does not have a blank check. He cannot plead guilty and abandon his appeal rights directly, and he should not be allowed to do so indirectly by an inept performance."25 Had the trial judge based his decision solely on the ability of the particular defendant to handle a capital case, rather than on the nature of the charge itself, Justice Mosk would have dissented. ${ }^{26}$ Justice Richardson also concurred, disapproving the low standard of review for such waivers mandated by the United States Supreme Court, and suggesting reservations about the per se standard of reversal

14. Id. at 944, 671 P.2d at 847-48, 196 Cal. Rptr. at 343-44.

15. Id. at 945,671 P.2d at $848,196 \mathrm{Cal}$. Rptr. at 344 .

16. Id. (citing Faretta, 422 U.S. at 835).

17. Id. (citing Faretta, 422 U.S. at 835).

18. Faretta, 422 U.S. at 834.

19. 34 Cal. 3 d at 946,671 P.2d at $848-49,196$ Cal. Rptr. at 344-45 (quoting Faretta, 422 U.S. at 834$)$.

20. Id. at 946,671 P.2d at 849,196 Cal. Rptr. at 345.

21. Id. at $946-48,671$ P.2d at 849-50, 196 Cal. Rptr. at 345-46. See, e.g., Bittaker v. Enomoto, 587 F.2d 400, $402-03$ (9th Cir. 1978), cert. denied, 441 U.S. 913 (1979); People v. Freeman, 76 Cal. App. 3d 302, 309-10, 142 Cal. Rptr. 806, 809-10 (1977).

22. $34 \mathrm{Cal}$. 3d at 948,67 I P.2d at 850, $196 \mathrm{Cal}$. Rptr. at 346 (Mosk, J., concurring).

23. Id. at 948-49, 671 P.2d at 850, 196 Cal. Rptr. at 346-47 (Mosk, J., concurring) (citing People v. Chadd, 28 Cal. 3d 739, 752, 621 P.2d 837, 844, 170 Cal. Rptr. 798, 805 (1981)).

24. Id. at 949,671 P.2d at 851,196 Cal. Rptr. at 347 (Mosk, J., concurring).

25. Id. at 950,671 P.2d at 851, 196 Cal. Rptr. at 347 (Mosk, J., concurring).

26. Id. 
adopted by the majority. ${ }^{27}$

The majority made no attempt to consider the state's mterest in the fairness of the proceedings raised by Justice Mosk in his concurrence. ${ }^{28}$ It also failed to address the trial court's concern with the defendant's ability to cope with a capital charge, ${ }^{29}$ except to pronounce the nature of the charge irrelevant. ${ }^{30}$ As the next Section will suggest, this outcome was the product of the court's unnecessarily strict interpretation of Faretta.

\section{B. Faretta and the Right to Self-Representation in California}

In response to Faretta, the California Supreme Court has slifted the direction of California pro se defense law. Prior to Faretta, California courts had relied on the wording of the California Constitution, which then guaranteed the defendant's right "to appear and defend im person and with counsel." ${ }^{31}$ In People v. Sharp, ${ }^{32}$ the California Supreme Court interpreted this language to mean that a defendant had a nonconstitutional right to waive the assistance of counsel, but no concomitant constitutional right to self-representation at trial. ${ }^{33}$ In other words, a defendant could waive counsel, but the trial court retained the discretion to accept or reject the waiver.

In Faretta, the United States Supreme Court used much the same historical material quoted by the California Supreme Court in Sharp to arrive at a very different conclusion. Although the California court found no independent right to a pro se defense, the history of self-rep-

27. Id. at 950-51, 671 P.2d at 851-52, $196 \mathrm{Cal}$. Rptr. at 347-48 (Richardson, J., concurring). He awaited "further instruction on the point [of the appropriate harmless error standard] from the high court which originated the Faretta principle." Id. at 951, 671 P.2d at 852, 196 Cal. Rptr. at 348 (Richardson, J., concurring).

28. Id. at 949, 671 P.2d at 850-51, 196 Cal. Rptr. at 346-47 (Mosk, J., concurring).

29. Id. at $941-42,671$ P.2d at 846,196 Cal. Rptr. at 342 .

30. Id. at 944-45, 671 P.2d at 847-48, 196 Cal. Rptr. at 343-44.

31. CAL. Const. art. $1, \S 13, \mathrm{cl} .3$ (1849, amended 1972) (current version at CAL. Const. art. $1, \S 15$, ci. 3) (einphasis added).

32. 7 Cal. 3d 448, 499 P.2d 489, 103 Cal. Rptr. 233 (1972).

33. The court stated the: the conjunction between "in person" and "with counsel" meant that those two terms must be read together. Therefore, a person could perhaps waive counsel but could not demand a constitntional right to proceed alone. The court held that while there was a right to self-representation, it was not of constitutional weight and was therefore subject to the discretion of the court. Id. at 461, 499 P.2d at 497-98, 103 Cal. Rptr. at 241-42. To read the language to give a person the right to appear alone would be to "read the phrase in person and with counsel' as 'in person or with counsel." " Id. at 457, 499 P.2d at 495, 103 Cal. Rptr. at 239. At about the saine time California had dropped "in person and with counsel" from the constitution and replaced it with "to have the assistance of counsel for the defendant's defense, to be personally present with counsel . . ." CAL. ConST. art. 1, $\S 15, \mathrm{cl}$. 3. Accompanying penal code provisions tracked the old language. The Sharp court construed them also to provide no absolute right to self-representation. $7 \mathrm{Cal}$. 3d at 463-64, 499 P.2d at 498-99, $103 \mathrm{Cal}$. Rptr. at 242-43 (appendix). 
resentation, ${ }^{34}$ the corresponding federal statutory provision, ${ }^{35}$ and the structure of the sixth amendment ${ }^{36}$ led the U.S. Supreme Court to conclude that there is an independent constitutional right to proceed without an attorney.

Essential to the Faretta Court's reasoning was its concern with protecting what it saw as a basic aspect of American justice-the individual autonomy of the defendant. It is a fundamental tenet of American culture that individuals are responsible for shaping their own destinies. ${ }^{37}$ Supplying a defense to the individual does not sufficiently protect this individual autonomy; rather, the defense must be the individual's own. ${ }^{38}$ The only justification for attorneys' customary control over the criminal defense is the presumption that defendants have chosen to permit it. ${ }^{39}$ It is, after all, the defendant who will be punished if the defense fails. But whatever the outcome, a criminal defendant has the right to be heard on his own terms. ${ }^{40}$ After recognizing that there are countervailing rights of the defendant and of society, the Court held that when they collide, the principle of defendant autonomy inust prevail. $^{41}$

Faretta thus established a constitutionally mandated right to defend pro se. The California courts have since defined both the paraineters of this right and the procedures necessary to invoke it. For example, a trial court may always prevent the use of the right as a dila-

34. Faretta, 422 U.S. at $821-32$.

35. 28 U.S.C. $\S 1654$ (1976) (cited in Faretta, 422 U.S. at 813). The Court pointed out that such a statutory provision has existed since 1789 on the federal level and linked that fact with state court and other federal decisions to strengthen the claim that the right had constitutional stature. Faretta, 422 U.S. at 813-17. The Sharp court in contrast stated that the right to self-representation was "expressly conferred only by statute." Sharp, 7 Cal. 3d at 455, 499 P.2d at 493, 103 Cal. Rptr. at 237.

36. Faretta, 422 U.S. at $819 \&$ n.15. The Court emphasized that the rights the amendment speaks of belong to the accused and that they include the right to the assistance of counsel. Id. at 819-21. "The counsel provision supplements this design. It speaks of the 'assistance' of counsel, and an assistant, however expert, is still an assistant." Id. at 820 .

37. The importance to American culture, and to western culture generally, of personal autonomy is almost a commonplace. A powerful 17th century illustration of (and commentary on) this driving concern for control over one's own destiny is found in J. MiLton, Paradise Lost, Book I, Lines 258-63 (1667), where a vanquished Satan looks over his desolate realm and proclaims:

\section{Here at least}

We shall be free; th'Almighty hath not built Here for bis envy, will not drive us hence:

Here we may reign secure, and in my choice

To reign is worth ambition though in Hell:

Better to reign in Hell, than serve in Heav'n.

38. Faretta, 422 U.S. at 821.

39. Id. at $820-21$.

40. Id. at 834 .

41. Id. at 832-34. 
tory tactic. ${ }^{42}$ If the right is not invoked in a timely manner, the trial court has the discretion to grant or deny the right. ${ }^{43}$ If the right is invoked im a timely manner, the court must grant it unless the defendant is not mentally competent to knowingly waive her right to counsel. ${ }^{44}$ That the defendant might be incapable of properly defending herself in a complex judicial proceeding does not defeat the right; ${ }^{45}$ poor selfrepresentation is insufficient grounds for reversal. ${ }^{46}$ Misbehavior and obstruction of proceedmgs by the defendant in court, however, may justify the revocation of the pro se right. ${ }^{47}$

Courts have generally interpreted a waiver of counsel under Faretta to include a waiver of most of the protections that the assistance of an attorney can bring. ${ }^{48}$ However, Faretta does leave to trial courts the option of supplying standby counsel to assist pro se defendants. $^{49}$ But courts have generally treated that option as discretionary, and not a right to which defendants are entitled. ${ }^{50}$ The Faretta Court stated that when an accused "manages his own defense, he relinquishes, as a purely factual matter, many of the traditional benefits associated with the right to counsel."s! However, this observation is less a statement of doctrine than an empirical description of what happens

42. Joseph, 34 Cal. 3d at $944 \&$ n.2, 671 P.2d at $847 \&$ n.2, 196 Cal. Rptr. at $343 \&$ n.2. The court notes that the timeliness requirement is to prevent misuse of the Faretta mandate to delay proceedings unjustifiably. Id. at 944 n.2, 671 P.2d at 847 n.2, 196 Cal. Rptr. at 343 n.2; see also People v. Tyner, 76 Cal. App. 3d 352, 354-55, 143 Cal. Rptr. 52, 53 (1977).

43. See supra note 42.

44. Joseph, 34 Cal. 3d at 943,671 P.2d at 847, 196 Cal. Rptr, at 343. This is the significance of self-representation as an independent constitutional right. Where there is simply a question of waiving the right to counsel, the courts have discretion to accept or refuse the request. However, when self-rcpresentation became an independent constitutional right, the discretion became sharply limited. See supra note 33 and accompanying text.

45. Joseph, 34 Cal. 3d at 943, 671 P.2d at 847, 196 Cal. Rptr. at 343.

46. E.g., People v. Cervantes, 87 Cal. App. 3d 281, 293-94, 150 Cal. Rptr. 819, 827 (1978); People v. Lopez, 71 Cal. App. 3d 568, 574, 138 Cal. Rptr. 36, 39 (1977).

47. Ferrel v. Superior Court, 20 Cal. 3d 888, 891, 576 P.2d 93, 95, 144 Cal. Rptr. 610, 612 (1978).

48. This would account for the courts' concern with the warnings to be given to a defendant attempting to waive the right to an attorney. See, e.g., People v. Longwith, 125 Cal. App. 3d 400, 408-09, 178 Cal. Rptr. 136, 140-41 (1981); People v. Paradise, 108 Cal. App. 3d 364, 367-69, 166 Cal. Rptr. 484, 486-87 (1980); People v. Lopez, 71 Cal. App. 3d 568, 571-74, 138 Cal. Rptr. 36, 3839 (1977). Some protections remain for the pro se defendant; e.g., California courts must warn a pro se defendant of the danger in testifying to the right against self-incrimination. People $v$. Cervantes, 87 Cal. App. 3d 281, 288-91, 150 Cal. Rptr. 819, 823-25 (1978). However, the presumption underlymg the whole guarantee to the right to counsel is that rights cannot be properly protected by relying on the court; rather, an attorncy is required. See infra notes 65-87 and accompanying text.

49. Faretta, 422 U.S. at 834 n.46.

50. McKaskle v. Wiggins, 104 S. Ct. 944, 953-54 (1984) (Faretta does not require trial judge to permit "hybrid representation"); Locks v. Sumner, 703 F.2d 403, 407-08 (9th Cir. 1983) (no court has decided defendant has absolute right to advisory counsel).

51. Faretta, 422 U.S. at 835. 
in the courtroom. That is, Faretta need not be understood as a statement that such a loss is desirable; in fact the Court noted that in previous right-to-counsel decisions, it had emphasized the importance of the right to a fair trial and the necessary role played by counsel in ensuring that fairness. ${ }^{52}$

As the Court's reference to discretionary standby counsel acknowledges, waiver of counsel need not inean that all of the protections generally associated with representation must be lost. The Court assigned to standby counsel the functions of assisting the defendant if requested and, at the extreme, rescuing an accused in the event that termination of her self-defense is necessary. ${ }^{53}$ Counsel can even be appointed over the defendant's objection. ${ }^{54}$ All of these possibilities reside, however, $\mathrm{i}$ the judicial basement of a footnote. This leaves the appointınent of standby counsel as apparently nothing more than something a court is free to offer to criminal defendants should the judge see fit.

With its discussion of standby counsel cast only in a footnote, Faretta might, despite Justice Mosk's protest, ${ }^{55}$ be read as mandating a defendant's absolute right to defend himself. The accused need only be capable of waiving his right to counsel knowingly and with "eyes open." 56 Indeed, the defendant need not demonstrate an ability to mount an effective defense, ${ }^{57}$ nor even a rudimentary knowledge of legal technicalities. ${ }^{58}$ The dangers inherent in self-representation are a burden the defendant inust bear fully and without relief: the ineffectiveness of his pro se defense will not be ground for appeal. ${ }^{59}$

However, as the Court has developed its doctrine of pro se defense, the implications of the Faretta footnote on standby counsel have become increasingly significant. Recently, in McKaskle v. Wiggins, ${ }^{60}$ the Umited States Supreme Court specifically addressed some of the implications of the defendant's right to waive legal counsel, qualifying a strict reading of Faretta. According to the McKaskle Court, the essence of the right to a pro se defense is not in being totally alone in preparing a defense, but in controlling the defense and being perceived by the jury as doing so. ${ }^{61}$

The McKaskle Court held that standby counsel, whether re-

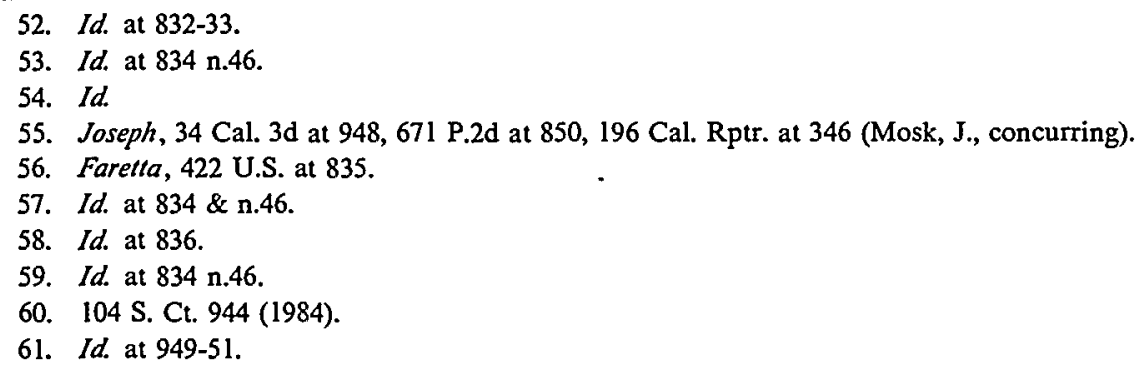


quested or appointed over the defendant's objection, ${ }^{62}$ need not stand inute. Rather, standby counsel inay enter objections or make other moves to further the defendant's defense, even against the defendant's will. ${ }^{63}$ Counsel may also on her own take steps to aid the defendant in surmounting procedural hurdles, thereby freeing the judge from this task. The defendant, the Court stated, "does not have a constitutional right to receive personal instruction from the trial judge on constitutional procedure," nor is the judge constitutionally required "to take over chores for a pro se defendant that would normally be attended to by trained counsel as a matter of course." ${ }^{\prime 4}$ In setting limits to the pro se right, the court has identified those areas where efforts can be made to protect the essential fairness and adequacy of trials as required by the sixth and fourteenth amendments without violating the Faretta right to self-defense. By expanding the linits within which standby counsel may constitutionally function, McKaskle increases the potential efficacy of such counsel in protecting a defendant's right to a fair trial.

Still, under current Supreme Court doctrine, criminal defendants who elect to defend themselves stand alone before the state. They need only establish in a timely manner their knowing and voluntary decision to waive the assistance of legal counsel. Protections assuring the availability of information necessary to a coinpetent criminal defense remain subject to judicial discretion. Yet, as the next Section of this Coinment demonstrates, the right to a fair trial, potentially impaired when a defendant proceeds pro se, has been the pervasive concern of sixth ainendment jurisprudence. And the concern with fair procedures extends not only to individual defendants, but also to society as a whole. This overriding social desire to establish a just legal system should receive more consideration in cases involving pro se representation. It calls for mandatory aid to pro se defendants-aid which Faretta and McKaskle treat as discretionary.

II

The Sixth Amendment, the Assistance of Counsel AND the Right to a FaIR TRIAL

\section{A. The Development of the Right to Counsel}

The sixth amendment to the United States Constitution protects the criminal defendant by establishing the right "to be informed of the nature and cause of the accusation; to be confronted with the witnesses

62. Id. at 954 .

63. Id.

64. Id. 
against him; to have coinpulsory process for obtaining witnesses in his favor, to have the Assistance of Counsel for his defence."65 This is not simply a list of unconnected guarantees but, as the Faretta Court noted, "a coinpact stateinent of the rights necessary to a full defense"66 and "basic to our adversary systein of criminal justice." 67

The basic right protected by the guarantees of the sixth annendment is the right to a fair trial. It is a right held not only by the individual defendant but, in a critical sense, by every member of society. This societal right has two important aspects. First, eacli member of society to some degree identifies witls the criminal defendant, conceiving of himself in a similar phight. One commentator has noted that, "from the moment the offender is perceived as a surrogate self, this identification calls for a 'fair trial' for him before he is pumislied, as we would have it for ourselves." 68 Second, and perhaps more significant, society in general has a crucial interest in perceiving itself as a body that is fundamentally good, fair and just. Indeed that concern for fairness, to protect the individual froin the power of the state, permeates the sixth ainendinent.

As sixth ainendinent jurisprudence developed, the courts began to analyze inore critically the requirements of a fair trial. The riglit to counsel was early seen as crucial to the prospect of a fair trial. Thus, the sixth ainendinent debate gradually progressed from whether a state could deny counsel to whether a state had to supply counsel to those who could not secure their own. In Powell v. Alabama, ${ }^{69}$ the Supreme Court required the states, as part of their due process obligation, to provide effective assistance of counsel for state capital defendants who could neitlier secure counsel nor adequately defend theinselves. ${ }^{70}$ The opinion is often quoted for its eloquent description of the plight of even an educated person confronted by the complexities of a trial: "Witliout

65. U.S. CONST. amend. VI. Initially, the sixth amendment was a brake on the power of the federal government alone, guaranteeing nothing to the state criminal defendant. It was only with the passage of the fourteenth amendment with its fairness guarantee-c"nor shall any State deprive any person of life, liberty, or property, without due process of law"-that various elements of the Bill of Rights began to be applied to the states to protect values regarded as fundamentaI to society. U.S. CoNST. amend. XIV. For the application of the sixth amendment right to counsel to state felony trials, see Gideon v. Wainwright, 372 U.S. 335, 341-42 (1963).

Of course, states liad their own forms of protection for the criminal accused, some stronger and some weaker than those required on the federal level. For a treatment of the development of the right to connsel before Gideon, see generally W. BEANEY, THE RIGHT TO COUNSEL IN AMERICAN Courts (1955).

66. Faretta v. California, 422 U.S. 806,818 (1975).

67. Id.

68. Goldstem, The State and the Accused: Balance of Advantage in Criminal Procedure, 69

YALE L.J. 1149, 1150 (1960).

69. 287 U.S. 45 (1932).

70. Id. at 71 . 
[the guiding hand of counsel], though he be not guilty, he faces the danger of convietion because he does not know how to establish his innocence." $" 11$

After expanding the right to appointed counsel to all indigent federal defendants, ${ }^{72}$ the Court refused to extend that right to defendants in state proceedings. In Betts v. Brady, ${ }^{73}$ the Court concluded that fair trials were possible even when a defendant was not represented by counsel. Thus, the Constitution did not require the states to supply counsel to all indigent noncapital defendants. ${ }^{74}$ Appointed counsel was required only where circuinstances demonstrated it was vital to a fair trial. $^{75}$

After twenty years of case-by-case fairness analysis, the Supreme Court overruled Betts in Gideon v. Wainright ${ }^{76}$ The "obvious truth" that an mdigent defendant "cannot be assured a fair trial unless counsel is provided for him"77 led the Court to require states to furnish counsel to all felony defendants who could not secure their own attorneys. The Court then extended this principle to deny states the right to imprison an unrepresented criminal defendant. ${ }^{78}$ However, the Court eventually concluded that counsel need not be provided where deprivation of liberty is not at issue. ${ }^{79}$ Since imprisoninent is a qualitatively different punishment from a fine, ${ }^{80}$ the Court found that the need for counsel to guarantee a fair trial is not as critical, and does not justify state-furmished counsel where the maximum possible penalty is monetary. ${ }^{81}$

In Johnson v. Zerbst, ${ }^{82}$ the Court noted that the right to the assistance of counsel is "one of the safeguards of the Sixth Ainendment deeined necessary to msure fundamental human rights of life and liberty." ${ }^{\text {" }}$ Legal representation is so important to a fair criminal trial that

71. Id. at 69.

72. Johnson v. Zerbst, 304 U.S. 458, 463 (1938).

73. 316 U.S. 455 (1942), overruled by Gideon v. Wainwright, 372 U.S. 335, 345 (1963).

74. Id. at 473. For a survey of the Court's fair trial rulings under the first ten years of the Betts standard, see W. BEANEY, supra note 65 , at 164-98.

75. Betts, 316 U.S. at $472-73$.

76. 372 U.S. 335 (1963).

77. Id. at 344 (emphasis added).

78. Argersinger v. Hamlin, 407 U.S. 25, 37 (1972).

79. Scott v. Illinois, 440 U.S. 367 (1979).

80. Id. at 373 .

81. The necessity for drawing a line where counsel must be supplied coines froin the perception that appointing counsel for all misdemeanors would be prohibitively expensive. See Argersinger, 407 U.S. at 37 n.7, and Scott, 440 U.S. at 373 (both addressing the issue of potential expense). Additionally, many misdemeanor cases involve no real dispute and only light punishinent. In those cases even those defendants who can afford counsel may not bother to retain legal assistance. To inandate counsel for indigents in those cases would be anomalous.

82. 304 U.S. 458 (1938).

83. Id. at 462 . 
refusal to permit a defendant to have an attorney ${ }^{84}$ and, indeed, refusal to supply one to those who qualify ${ }^{85}$ constitute a denial of the right to a fair trial. Inadequate counsel is also grounds for a new trial. ${ }^{86}$ Even sharing an attorney, which can have less impact on fairness than proceeding without one, can violate the sixtl amendment and render a conviction void, because a conflict of interest between defendants may destroy the adequacy of representation. ${ }^{87}$

\section{B. The Need for Counsel and the Defendant's Right to a Fair Trial}

The right to counsel is mextricably intertwined with the sixtlı amendment guarantee of a fair trial. The importance of the right to counsel as a safeguard of fairness becomes clear in the context of the modern crimmal trial. The modern trial is no longer simply a gathering of neighbors who collect every possible scrap of inforination and come to a collective judgment on the guilt or iumocence of their peer. ${ }^{88}$ It is an adversarial system controlled by a highly stylized and ritualized process. For the system to operate fairly, the opposing sides inust be balanced. In the words of Professor Morris, "the essence of the system is challenge - an incessant searching and a rigorous questioning of each governmental accusation, assertion, or decision at every stage of the criminal law process." 89

From the very start, lowever, the balance is skewed when a criminal defendant faces alone the skill of a prosecuting attorney. There are subtle technical distinctions that control what a person may say in court and how it may be said. ${ }^{90}$ Some evidence is admissible; some is not. Words such as "relevant," "material," and "competent" are part of a specialized courtroom jargon, and their ineanings are not obvious to the uninitiated. Particular issues can be raised only within certain time

84. Powell v. Alabama, 287 U.S. 45, 69 (1932).

85. Id. at 71-72. The development since Powell has been partly in defining what types of defendants qualify for the appointment of counsel: the capital defendant in Powell, 287 U.S. at 71 , the noncapital defendant whose rights could not be properly protected by the court in Betts, 316 U.S. at 472-73, all felony defendants in Gideon, 372 U.S. at 344, and misdemeanor defendants whom the state would imprison in Argersinger, 407 U.S. at 37 . The Scott Court refused to extend the protection to those misdemeanor defendants not faced with imprisonment. 440 U.S. at 373-74.

86. Strickland v. Washington, 104 S. Ct. 2052, 2064 (1984) (citing Cuyler v. Sullivan, 446 U.S. 335,344 (1980)).

87. Cuyler v. Sullivan, 446 U.S. 335, 348 (1980).

88. In the formative days of jury trial, the jury were themselves chosen because they were witnesses to the event in dispute and "[i]f some or all are ignorant, and say so on their oaths, they are to be excluded." 1 J. Stephen, A History of the CRiminal LaW of England 256 (1883). By the 14th century there was evidence of a trial where the jury had ceased to be witnesses and became judges of evidence given by others. Id. at 260-61.

89. Morris, Right to Counsel, in 1 EnCyClopedia of CRime AND Justice 278, 278 (S. Kadish ed. 1983).

90. Powell v. Alabama, 287 U.S. 45, 69 (1932). 
limits, and unless particular claims are made at the prescribed time and im the prescribed manner they may be considered waived.91 Such procedures are designed for those who know the rules; they can trap those who do not. ${ }^{92}$ A typical untramed defendant is no more likely to know her way through the trial ritual than the average layperson is to comprehend the intricacies of how a priest performs a religious ritual. However, the consequences to the defendant of failure im her trial ritual are far more severe. Without the aid of counsel, one may be "put on trial without a proper charge, and convicted upon incompetent evidence, or evidence irrelevant to the issue or otherwise inadmissible." 93

These highly technical details of the modern criminal trial are a response to the needs of the adversary system. This system is designed to lead to truth and fairness and to protect the individual defendant from abuse of the power of the state. With each side attempting to present the best possible arguments and evidence, the finder of fact will best be able to render a fair verdict. Procedural rules keep this quest for truth fair by preventing either side from providing inappropriate information to the factfinder. Thus, for the adversary system to remain properly balanced, a vigorous and knowledgeable defense for the accused is as essential as a probing prosecution and a neutral judge. ${ }^{94}$ If one party is unschooled in the law, the resulting imbalance not only damages the "sporting" aspect of the proceedings, ${ }^{95}$ but, more important, impairs the aim of the legal system that "justice . . . 'still be done." "96 As the Gideon Court stated: "This noble ideal [of every defendant standing equal before the law] cannot be realized if the poor man charged with crime has to face his accusers without a lawyer to assist him."

Although the right to a fair trial is prominent in the sixth amendment, the Faretta case demonstrates an inherent consitutional conflict. In Faretta the Court ruled that a defendant has an affirmative constitutional right to defend herself. ${ }^{98}$ However, the defendant also has a corresponding constitutional right to an attorney. As this discussion has deinonstrated, the danger that an uncounseled defendant in a complex

91. Schaefer, Federalism and State Criminal Procedure, 70 HARv. L. REv. 1, 8 (1956).

92. Id.

93. Powell, 287 U.S. at 69.

94. Morris, supra note 89 , at 278.

95. Brennan, The Criminal Prosecution: Sporting Event or Quest for Truth?, 1963 WASH. U.L.Q. 279, 279. In arguing for defense discovery of prosecution evidence, Justice Brennan underscored the idea that the salutary effect of discovery on the search for truth in the criminal trial was more important than the "sporting" complaint that the prosecution had no countervailing right to discovery of the defendant's information.

96. Johnson v. Zerbst, 304 U.S. 458, 462 (1938).

97. Gideon v. Wainwright, 372 U.S. 335,344 (1963).

98. See supra text accompanying notes 34-40. 
trial will be unable to mount an effective defense is so severe that demal of counsel makes the trial itself unfair and unconstitutional.99 "The Sixth Amendment recognizes the right to the assistance of counsel because it envisions [counsel in] a role that is critical to the ability of the adversarial system to produce just results." 100 The right to counsel protects the defendant, and a court is generally not required to accept a waiver of a right if it feels that the defendant will suffer as a result. ${ }^{101}$ The dilemma in Faretta is that a pro se defense involves at least a partial waiver of the right to counsel. If lower courts were to exercise their discretion to refuse a potentially harmful waiver of counsel, they would at the same time prevent the defendant from exercising her affirmative right to a pro se defense. Thus, by establishing an imdependent constitutional basis for the pro se right, the Faretta Court effectively ruled that the affirmative right to a pro se defense must prevail.

Self-representation, however, does not require relinquishinent of the entire underlying constitutional right to a fair trial. Exercising the Faretta right to self-representation, as ordimarily understood, costs the defendant the protection of counsel declared by the Supreme Court to be elemental to a fair trial. Thus, the defendant's surviving right to a fair trial renders the procedural protections necessary to fair trials constitutionally imperative.

\section{The Need for Counsel and Society's Interest in Fair Trials}

After Faretta, defendants who choose to represent themselves bear the full burden of preparing and arguing an adequate defense, though a court is perunitted to provide assistance at its own discretion. ${ }^{102}$ If defendants waive their right to legal counsel, society's duty to provide a fair trial is arguably extmguished. There is, however, a countervailing interest that society itself might claim. This interest is ordmarily complementary to, but potentially in conflict with, the defendant's right to self-representation. As Justice Mosk maintained in Joseph, "The state has an interest in the proceedings that cannot be extmguished." 103 Specifically, society has an overriding interest in the fairness of its trials. The goal of due process, which the sixth amendment guarantees, is to ensure "the reliability of the guilt-determining process-reducing to a minimum the possibility that any innocent individual will be

99. See supra notes $69-98$ and accompanying text.

100. Strickland v. Washimgton, 104 S. Ct. 2052, 2063 (1984).

101. See, e.g., Singer v. United States, 380 U.S. 24 (1965) (defendant's waiver of jury trial could not compel court to grant bench trial); Massie v. Sumner, 624 F.2d 72 (9th Cir. 1980), cert. denied, 449 U.S. 1103 (1981) (upholding state law forbidding waiver of death penalty appeal).

102. Faretta, 422 U.S. at 834 n.46.

103. 34 Cal. 3d at 949, 671 P.2d at 851, 196 Cal. Rptr. at 347 (Mosk, J., concurring). 
punished." 104

Even more important than the determination of the guilt or innocence of any particular individual defendant is the "crucial concern that the integrity of the process of ascertaining guilt or innocence never be impaired." 105 The cominuinty which conducts the legal proceedings is in a vital sense a participant in the legal process. Society's "strong interest in the accuracy and fairness of all its criminal proceedings"106 deserves protection. It is by no means clear that a defendant's waiver of her right to representation should be permitted where it threatens to impair the coinmunity's interest in fair judicial process. This notion has been reflected in judicial opimion. For example, in Singer $v$. United States, ${ }^{107}$ the Court held that although a defendant has the right to waive a trial by jury, she has no parallel right to deinand trial to a judge. ${ }^{108}$

The coinınunity interest in fairness is inost clearly reflected in capital cases. The death penalty remains extremely controversial. Even with the current resurgence of executions, inany courts resist imposing a death penalty and are receptive to plausible grounds for reversal when it is imposed. ${ }^{109}$ The due process standard looins especially large in capital cases, ${ }^{110}$ reflecting the severity and irrevocability of the penalty. ${ }^{111}$ Indicia of due process fairness far beyond what is required in the ordinary imprisonment case must be present before a death sentence will be upheld.

Yet Faretta ${ }^{112}$ and its California progeny ${ }^{113}$ hold that pro se de-

104. Kadish, Methodology and Criteria in Due Process Adjudication-A Survey and Criticism, 66 YALE L.J. 319, 346 (1957) (emphasis added).

105. Id.

106. Massie v. Sumner, 624 F.2d 72, 74 (9th Cir. 1980), cert. denied, 449 U.S. 1103 (1981).

107. 380 U.S. 24 (1965) (cited in Faretta, 422 U.S. at 819 n.15).

108. Id. at $34-35$.

109. To ensure the constitutionality of death sentences the Supreme Court has approved "bifurcated trials, sentencer discretion exercised in accordance with clear and specific guidelines, proportionality review, and the right of the defendant to present mitigating evidence at the penalty phase," declaring all of these except proportionality review to be essential. Goodpaster, The Trial for Life: Effective Assistance of Counsel in Death Penalty Cases, 58 N.Y.U. L. REV. 299, 317 (1983). The Supreme Court has since exphicitly held that proportionality review is not required by the eighth amendment. Pulley v. Harris, 104 S. Ct. 871, 876-81 (1984).

110. "Thus, although not every imperfection in the deliberative process is sufficient, even in a capital case, to set aside a state court judgment, the severity of the sentence mandates careful scrutiny in the review of any colorable claim of error." Zant v. Stephens, $103 \mathrm{~S}$. Ct. 2733, 2747 (1983); see also Radin, Cruel Punishment and Respect for Persons: Super Due Process for Death, 53 S. CAL. L. Rev. 1143, 1143 (1980). See generally Comment, Capital Punishment and the Waiver of Sentence Review, 18 HARV. C.R.-C.L. L. REv. 483 (1983).

111. See, e.g., the cases cited in Gillers, Deciding Who Dies, 129 U. PA. L. REv. 1, 46-47 nn. 215-25 (1980).

112. 422 U.S. at 834 n.46.

113. E.g., People v. Cervantes, 87 Cal. App. 3d 281, 291-93, 150 Cal. Rptr. 819, 825-27 (1978); see also Locks v. Sumner, 703 F.2d 403, 408 (9th Cir. 1983). 
fendants cannot rely on errors resulting from their own inadequate defense as grounds for appeal. In Joseph, itself a death penalty case, the court further ruled that the pro se right attaches equally no matter how serious the charge. ${ }^{114}$ The choice is painful for the court faced with a case flawed by the uncounseled defendant's errors. A review of the defendant's trial strategy for errors indicates that a pro se defense will virtually guarantee a second opportunity for acquittal. ${ }^{115}$ On the other hand, if a court refuses to review, it unay allow a defendant to be executed even though there was an available but unused defense. ${ }^{116}$

One might argue that froin the personal autonomy perspective, this dilemma does not exist. If an informed defendant chooses to defend herself, she has chosen to accept the results of her defense; society's sole duty is to permit her the fruits of her choice. However, this argument ignores the role of the community as an actor. If the defendant receives the death penalty, the community must be the executioner; if the defendant is imprisoned, the cominunity must be the jailor. The community has a strong imterest in not being forced into these roles by an uncounseled defendant. As one court has stated, society need not condone "state aided suicide." "117

As a response to this societal interest, states have passed laws which, for example, provide for automatic appeals of all death penalties. ${ }^{118}$ Such laws have withstood challenge because "a state niay require reasonable proceedings in order to protect its own interests in the fairness of its determmations." 119 This recognition of the community's interest is in stark contrast to the Faretta Court's overriding concern with the defendant's personal autonomy rights. Courts must recognize that the community's interest in its legal processes is at least as important as the individual defendant's rights. Indeed, society's overarching concern with fairness is the most powerful protection for an individual defendant.

Despite courts' generally narrow reading of Faretta, ${ }^{120}$ the Supreme Court has left room for protection of this fairness interest. In McKaskle, the Court allowed substantial involvenient of standby counsel, even over the defendant's objection, as long as the defendant's gen-

114. 34 Cal. 3d at $944-46,671$ P.2d at $846-48,196$ Cal. Rptr. at $342-44$.

115. Indeed, the Faretta Court voiced concern that defendants could maneuver an automatic second trial through their errors. Faretta, 422 U.S. at 834 n.46.

116. Powell v. Alabama, 287 U.S. 45,69 (1932).

117. Commonwealth v. McKenna, $476 \mathrm{~Pa} .428,441,383$ A.2d 174, 181 (1978); see also People v. Chadd, 28 CaI. 3d 739, 753 \& n.9, 621 P.2d 837, 845 \& n.9, 170 Cal. Rptr. 798, 806 \& n.9, cert. denied, 452 U.S. 931 (1981).

118. See, e.g., Cal. Penal Code $\$ 1239$ (b) (West 1982).

119. Massie v. Sumner, 624 F.2d 72, 74 (9th Cir. 1980), cert. denied, 449 U.S. 1103 (1981).

120. See supra notes. $49-59$ and accompanying text. 
eral control of the defense remamed intact. ${ }^{121}$ Actions of the attorney over the defendant's objection can never be justified from the autonomy perspective. Rather, the justification must flow from both the defendant's and society's mterest in fairness. That the Supreme Court has recognized this interest is a substantial step toward balancing the defendant's personal autonoiny and society's interest in fairness.

However, these imterests do not always conflict. In any particular proceeding, the defendant's fairness concern will coincide with society's fairness concern. Defendants who waive counsel generally do so to obtain what they believe will be a fair trial. Although there may be other reasons why defendants waive counsel, few involve a deliberate rejection of the "noble ideal" of standing equal before the law. Many waivers result from a clash with assigned counsel over trial strategy. ${ }^{122}$ Because the indigent defendant has neither leverage over the attorney nor freedoin to choose different counsel after such a clash, ${ }^{123}$ she may see no choice but to defend pro se. Other waivers result from distrust of the legal systein, and the assumption that the "judge's" lawyer is merely part of the general judicial conspiracy. ${ }^{124}$ Still others may arise from the defendant's conviction that no one can better represent the plight of the wrongfully accused than she can. ${ }^{125}$ None of these waivers is a deliberate choice to go naked into the arena; all are rejections of the traditional form of attorney control, expressing the desire that the defense be the defendant's own. ${ }^{126}$ This desire is a manifestation of the defendant's ultimate goal - a fair trial. Thus, the defendant may still want whatever assistance the attorney can provide; such standby counsel in no way violates the defendant's constitutional right to control her own defense.

If the values that courts are required to protect by providing counsel are truly fundainental, they remain so should the defendant choose self-representation. The defendant retains the right to a fair proceeding, and the community retains its interest as well. If the Supreme Court's continuing analysis of assistance of counsel as a fundamental protection of the right to stand "equal before the law" 127 is to retain its vitality, courts inust provide all reasonable assistance to enable pro se

121. McKaskle v. Wiggins, 104 S. Ct. 944, 953-54 (1984).

122. Chused, Faretta and the Personal Defense: The Role of a Represented Defendant in Trial Tactics, 65 CALIF. L. Rev. 636, 647-48 \& n.44 (1977).

123. Id. at 648 n.44.

124. Faretta, 422 U.S. at 834.

125. Standards for CRIminal Justice § 6-3.6(a) commentary at 6-39 (1978).

126. These rejections of counsel are consistent with the key value protected by Farelta-autonomy; however, they do not imply a rejection of assistance of counsel. See supra notes 37-41 and accompanying text.

127. Gideon v. Wainwright, 372 U.S. 335, 344 (1963). 
defendants to retain their equality. Many courts currently do so either through guidance from the bench or through some form of advisory counsel. However, a more appropriate solution is a mandatory form of standby counsel.

III

A Proposal For MaNDATORY STANDby AdVISORY COUNSEL

\section{A. Advisory Counsel and the Conflict Between Fairness and Autonomy}

Since Faretta explicitly authorizes standby assistant counsel, ${ }^{128}$ a form of standby counsel is a logical remedy for the risks a pro se defense poses to a fair trial. The recognized forms of standby counsel vary according to the needs they are meant to fill. Counsel may literally stand by to take over in case the defendant loses the right to selfrepresentation, in which case the attorney need only be present in the courtrooin. Alternatively, counsel may serve as a resource, consulting with the client outside of the courtroon or seated at the client's side, available for assistance. The inost extreme form of advisory counsel is known as co-counsel or hybrid representation, where both defendant and counsel participate in jury selection, statements and questioning. ${ }^{129}$ All of these forms have been employed in pro se defense cases, although no court has held any of them to be constitutionally required. ${ }^{130}$ Yet, in liglit of the McKaskle decision, all are constitutionally permissible. ${ }^{131}$

Standby counsel, in all but its most passive form, can serve to significantly lessen the negative effects of a pro se defense, without hampering its exercise. As the Supreme Court noted in McKaskle, the essence of the pro se right is the defendant's overall control of the defense. ${ }^{132}$ Standby advisory counsel can provide the aid needed to enhance a defendant's chances to make his own defense effective, even when the standby counsel actively participates in the trial more than the defendant desires. ${ }^{133}$

In Joseph, the California Supreme Court overturned the particular

128. Faretta, 422 U.S. at 834 n. 46 .

129. Many of the conflicts in hybrid representation arise from the failure to make a clear agreement, as in McKaskle, $104 \mathrm{~S}$. Ct. at $947-48$ (description of disagreement between defendant and counsel over respective roles). For a clear description of the forms of standby counsel, advisory counsel and co-counsel, see Comment, Pro Se Defendants and Advisory Counsel, 14 LAND \& WATER L. REV. 227, 228-31 (1979).

130. Locks v. Sumner, 703 F.2d 403, 407-08 (9th Cir.), cert. denied, 104 S. Ct. 338 (1983).

131. McKaskle, $104 \mathrm{~S}$. Ct. at $953,954$.

132. Id. at $949-51$.

133. Id. at 954 . 
defendant's conviction because he was not allowed to defond himself. Yct, in applying Faretta to all crimes, and holding that a Faretta violation is per se reversible, the court may have reduced future defendants' prospects for a fair trial. As a result of this decision, the court may soon face a case where a self-represented defendant's errors have earned him an undeserved death penalty. The defendant may be innocent, but unable to demonstrate it effectively in a courtroom, ${ }^{134}$ or guilty, but not deserving so severe a penalty. And, if the court follows the traditional position that self-representation errors are not reviewable, it may find itself allowing a defendant to be executed for being too suspicious of society to trust his defense to one of its officers. ${ }^{135}$ The potential tragedy is perhaps not as drainatic in noncapital cases, but inay still be devastating.

The California Supreine Court can avert this dilemma by making standby advisory counsel inandatory in all criminal prosecutions where imprisonment may result. ${ }^{136}$ The court has the power to make prophylactic rules to protect defendants and the integrity of the system. For example, four wceks after the Joseph decision, in People v. Mroczko, ${ }^{137}$ the supreme court ordered trial courts appointing attorneys to require defendants to consult with separate counsel before sharing legal representation. This rule is designed to ensure that defendants waiving their right to individual counsel fully realize the likelihood that a conflict of interest with codefendants will weaken their own defense. ${ }^{138}$ The court should use the same power to direct trial courts to appoint standby advisory counsel for defendants who wish to proceed pro se. ${ }^{139}$ Such a

134. Powell v. Alabama, 287 U.S. 45, 69 (1932).

135. The defendant "will bear the personal consequences of a conviction," Faretta, 422 U.S. at 834, and "cannot thereafter complain that the quality of his own defense amounted to a denial of "effective assistance of counsel." Id. at 835 n.46. The combination of these two factors makes it more likely that courts will have to choose whcther to abide by them and allow an inept pro se defendant to be executed.

136. This is the same distinction used by the Supreme Court in deciding whether the appointment of counsel for an indigent should be required. See supra note 81. It would certainly be anomalous to inandate the appointment of advisory counsel where ordinary counsel is not required.

137. 35 Cal. 3d 86, 672 P.2d 835, 197 Cal. Rptr. 52 (1983).

138. Id. at 115,672 P.2d at 853,197 Cal. Rptr. at 70.

139. The reasons for appointing standby counsel apply equally to indigents and nonindigents. The unrepresented nonindigent is as likely as the indigent to be disadvantaged by lack of knowledge of courtroon rules, procedures and tactics; that is consistent with the Powell Court's insight that even the educated defendant is not likely to know how to mount his dcfense "even though he have a perfect one." Powell v. Alabama, 287 U.S. 45, 69 (1932). Faretta does not limit standby counsel to indigents. Faretta, 422 U.S. at 834 n.46. How and whether mandatory standby counscl can be appointed for nonindigents is problematic for constitutional rcasons. It is not clear that a defendant can be forced to hire a standby attorney. Moreover, if the defendant objccts, a court's power to appoint standby counsel and bill the defendant is questionable. Alternatively, since the number of pro se defendants is not very large, the court could simply appoint the standby counsel and absorb the cost. 
rule would significantly alleviate the danger to fairness that a pro se defense may currently represent for the defendant, without trespassing on his Faretta and McKaskle rights. In so doing, the court will be following the spirit and the letter of the sixth amendinent. The defendant will have his own defense, and at the same time, assistance of counsel.

Nonetheless, potential conflict between autonomy and fairness remaims. Even given the nierely advisory nature of the proposed counsel, a moment may still arise when the defendant's assertion of autonoiny may compromise the fairness of his or her trial. The defendant niay insist on an action which the court and the attorney both recognize as foolisl. The McKaskle Court makes it clear that when such conflicts arise, the defendant's decision must prevail. ${ }^{140}$ Thus, the proposal for mandatory advisory counsel has a necessary limit. But, by niaximizing the likelihood that the defendant will make informed choices, such assistance can minimize the nionents of conflict and contradiction. Thus, the prospect of a fair trial will be enhanced. Even in those instances where the defendant refuses the advice given, the community will have done all it can to protect its interest in fairness while still remaining true to the fundamental primciple of individual autononiy.

\section{B. The Role of Advisory Counsel}

Once standby counsel becoines mandatory, the role of sucl counsel must be defined. McKaskle clearly finds high levels of participation by standby counsel constitutionally permissible. ${ }^{141}$ And, standby counsel is a desirable response to the fairness risks of a pro se defense. However, the exact nature of the proposed standby counsel is a coniplex question. Under the proposed nodel of standby counsel, the California Supreme Court should require trial courts to supply a pro se defendant with counsel that will function as an advisor, providnig him with sufficient knowledge to make intelligent choices. This role represents a median between the extrenies of hybrid representation and completely passive standby counsel. Under this approacli, the defendant remains in charge of the defense and nrakes all necessary decisions, but with the help of an attorney to explain the ramifications of the various alternatives.

This level of assistance best satisfies the need to protect the defendant's freedom of choice while supplying him with infornation that can increase the chance that the choice will be well considered. It also avoids some of the problems inherent in a more active standby role.

140. McKaskle, $104 \mathrm{~S}$. Ct. at 953, 955-56. While the McKaskle Court's position that defendant autonomy must eventually prevail is subject to debate, this Comment nevertheless assumes its validity.

141. Id. at $954-55$. 
For example, the hybrid form of representation has greater potential for courtroom disorder, as McKaskle itself reveals. ${ }^{142}$ Clashes are likely between counsel and client over the division of roles. Simply to decide these disputes in defendant's favor does not resolve the problem, since the disputes are themselves disruptive. Requiring the inore passive form of involvement proposed here would provide the information a defendant lacks, while preserving the trial court's flexibility. Nevertheless it remains in the trial court's discretion to authorize greater attorney involvement.

By stopping short of hybrid representation, this limited form of standby counsel conforins most closely to Faretta's authorization of standby counsel to "aid the accused if and when the accused requests help . . . "143 This proposal also eliminates any ambiguity concerning control of the defense. Sucl uncertainty in the jury's eyes can be especially damaging to the defendant. ${ }^{144}$

\section{The Standard of Review for Pro Se Errors}

\section{Review of the Defendant's Actions}

The most drastic result of Faretta and its Califorma progeny is the new standard for appellate review of pro se defense errors. These courts refuse to consider errors made by the pro se defendant to be grounds for reversal. ${ }^{145}$ This propliylactic rule prevents defendants from exploiting their courtroom blunders to obtain a second trial ${ }^{146}$ and removes any temptation to deliberately salt the trial with reversible errors. It is a legitimate response to the assumption that pro se defendants are particularly likely to inake serious errors. ${ }^{147}$ Indeed, it is also likely to discourage soine defendants froin representing themselves by increasing the severity and finality of error.

But when a pro se defendant acts in reliance on standby counsel's advice, this no-review rule is no longer appropriate. The defendant relying on counsel is, in effect, an extension of the attorney. Thus, the defendant deserves the same review of erroneous decisions taken on counsel's advice that would take place if the advising attorney had personally made those decisions. ${ }^{148}$ Where the defendant refuses to listen

142. Id. at $947-49$.

143. Faretta, 422 U.S. at 835 n.46 (emphasis added).

144. The Court in McKaskle pointed to such ambiguity as one of the dangers involvcd in hybrid representation. McKaskle, $104 \mathrm{~S}$. Ct. at 951, 953-55.

145. Faretta, 422 U.S. at 834 n.46.

146. Id.

147. Id. at 834-35.

148. The minimuin standard for effective assistance of counsel is set by Strickland v. Washington, 104 S. Ct. 2052 (1984). The proper measure of attorney performance is reasonableness under current professional norms. Id. at 2064-65. Judicial scrutiny of attorney performance must 
or acts against counsel's advice, the Faretta no-review rule is justified.

\section{Review of the Attorney's Actions}

There are two aspects to the review of advisory counsel's actions. The attorney's actions may be reviewed when a defendant attempts to gain relief for her own ineffective actions taken on the attorney's advice. The attorney may also face review when the disappointed defendant brings a malpractice action. In both situations, the same principles apply.

When serving as advisory counsel, the attorney, by definition, does not have control over the case. She can only give advice and do her best to dissuade the defendant from inaking fatal errors. However, it will be difficult to judge the attorney's actions wlien a convicted defendant blames her for his predicament. It is clear that counsel cannot be held responsible for the defendant's actions taken agamst her advice; the defendant in that situation is a completely independent agent.

To avoid a swearing contest between the defendant and his attorney on direct appeal, an adequate record detailing the attorney's recommmendations is required. However, if the attorney were to communicate with the judge each tnne the defendant refused advice, the defendant's case might be prejudiced. Rather, a practical solution lies in the procedure suggested for attorneys faced with perjurious clients. The attorney must make an appropriate record of her advice without revealing the facts to the court. ${ }^{149}$ Similarly, the record of the advisory counsel could be sealed and turned over to the court at the end of eacli day, to assure its contemporaneity. This record would reniain sealed unless the source of the defendant's actions becoines the subject of a future case. Such a practice would establish an appropriate record, ensure an unprejudiced defense, and protect the advisory counsel from spurious claims.

However, a contenporaneous record will be of limited use when the defendant claims that the advisory counsel sliould liave given ad-

be highly deferential. Id. at 2065-66. The convicted defendant must identify the specific acts or omissions that do not result from normal professional judgment. Id. at 2066. Even where there is an unreasonable error by counsel, the defendant must, in all but a few situations, demonstrate actual prejudice: "that there is a reasonable probability that, but for counsel's unprofessional errors, the result of the proceeding would have been different. A reasonable probability is a probability sufficient to undermine confidence in the outcome." $I d$. at 2068. The standard for effective assistance of advisory counsel is not fully developed since it is still an infrequent role; the standard should be analogous to those applying to regular counsel. Particularized standards will develop as more attorneys serve in the advisory counsel position.

149. Standards For CRIMINAL Justice, supra note $125, \S 4-7.7$, at $4-95$ (withdrawn). The attorney may do so, " for example, by having the defendant subscribe to a file notation, witnessed if possible, by another lawyer." " Lowery v. Cardwell, 575 F.2d 727, $731 \mathrm{n} .5$ (9th Cir. 1978) (quoting STANDARDS For CRIMINAL JUSTICE $\$ 7.7$ commentary at 277 (1971)). 
vice in a particular situation, but did not. An omission of this sort will be absent froin the conteinporaneous record. Thus, the court should look at the advice the defendant claims should have been given, the importance of that advice to the outcome of the trial, and any justification for the attorney's failure to give it. However, this standard must take into account the difficulty of the attorney's position in the advisory role.

Similarly, in a malpractice action, the wisdom of the attorney's advice must be assessed $\mathrm{m}$ the context of the entire record, mcludimg the defendant's previous decisions. Factfinders in malpractice suits often must distimguish between advice taken and advice ignored. Since this is a common problem in malpractice actions, the danger of attorney hability for defendant errors is no greater in the standby counsel context.

\section{Defendant Hostility}

If it is true that many defendants choose a pro se defense because they distrust court-appointed attorneys, forcing another attorney upon such defendants inay seem to be merely another version of the same intrusion. For the defendant whose hostility runs deep, counsel will probably be of little benefit; however, at least the resource will be available, and some defendants will take advantage of it. Further, to the degree that a defendant's hostility is rooted in resentment over having his wishes ignored by the attorney, the fact that the defendant will be in control might itself diffuse hostility and make the defendant more amenable to advice. The Faretta court emphasized that forcing an attorney upon a hostile defendant vitiates much of the good that an attorney can do. ${ }^{150}$ Thrustimg an advisor on a defendant who retains the freedom to accept or reject advice is less likely to have that negative impact since personal autonomy is preserved.

Finally, even if the defendant resents the assignment of an advisor, the community's imterest in the fairness of its proceedimgs justifies standby counsel nonetheless. Just as communities make law libraries available to defendants who decline to use them, commumities can make standby counsel available even if the defendant refuses to histen. Although the effect of advisory counsel may be minimal for a hostile defendant-especially if the defendant ignores all of the attorney's advice - the community will have made a good faith attempt to give the defendant all of the information and skill necessary to preserve his rights at trial.

150. Faretta, 422 U.S. at 834 . 


\section{CONCLUSION}

The California Supreme Court's decision in People v. Joseph represents an unnecessarily absolute reading of the defendant's right to a pro se defense under Faretta. The California court has effectively limited a trial court's discretion to deny timely motions for pro se defense, regardless of the nature of the crime and the severity of tlie penalty. As a result, defendants who resist attorney representation may face the death penalty or long prison terms after inadequately contested trials. This Comment has maintained that faithfulness to the sixth annendment guarantee of a fair trial need not be abrogated under Faretta.

Mandatory standby counsel offers a ineans for ineeting the interests of all parties to the judicial process. Defendants, while maintaining control over their defenses, would have access to the information necessary for an effective defense. Courts would no longer be required to act as defense attorneys for uninformed defendants, and trial processes would not be hampered by a defendant's lack of technical expertise. Appellate courts would be able to presume that a defendant's decisions were made strategically rather than inadvertently. Prosecutors could act as fully effective adversaries, confident that the advised defendant is a worthy opponent. Moreover, prosecutors would not be concerned about alienating a jury by appearing to take advantage of a helpless defendant. Finally, the community as a wliole would benefit from a system of crimmal justice that, in accordance with the sixth amendment, guarantees a fair trial even to the pro se defendant. Society could rest assured that it has done all in its power to see that only the guilty will be pumished, and that the guilty will receive only the sentences they deserve.

John H. Pearson*

* A.B. 1968, University of Notre Dame; M.Th. 1971, University of Notre Dame; third-year student, Boalt Hall School of Law, University of California, Berkeley. 